(C) 1982 ISIJ

\title{
低炭素鋼におけるMnS系介在物の形成過程
}

\section{Formation of Manganese Sulfide in Low Carbon Steel}

\author{
Yoichi Ito, Noboru Yonezawa, and Kaichi Matsubara
}

\begin{abstract}
Synopsis:
Steels containing $0.25 \%$ carbon, $0.03 \%$ sulfur and 0.3 to $1.2 \%$ manganese were melted and quenched at various temperatures between the final stage of solidification and $400^{\circ} \mathrm{C}$. The number, volume fraction and distribution of sulfides were investigated in connection with the grain boundary and dendritic structure.

Sulfides were grouped into two categories; the first was crystallized by a eutectic reaction and the second was precipitated from solid steel. The increase in manganese content and cooling rate was favorable to the formation of eutectic sulfides. These were mainly distributed at grain boundaries and interdendritic regions. On the other hand, precipitated sulfides increased in number as the manganese content and cooling rate decreased. These sulfides were classified into the colony type and non-colony type. The former was observed mostly at grain boundaries, and the latter tended to be precipitated within grains and dendrite arms.
\end{abstract}

\section{1. 緒言}

$\mathrm{SIMS}^{1)}$ は鋳鋼けけの MnS 系介在物（以後硫化物と呼ぶ） を I 型，II 型，III型に分類するとともに，II 型はＩ型や III型に比べて鋳造材の靶性を大きく低下させることを示 した。一而，熱間加工温度において硫化物は I 型， II 型，㸪型の順に変形能が大きくなると言われている ${ }^{2)}$. 変形能が大きく，したがつて長く伸びた硫化物注ど，そ れと直角方问の䩚性を低卜させることはもちろんである $か^{33}$ ， その空間的分布の影響もまた無視することはでき ない4)。一般にI型や开型は単独に分散しているのに対 し，II型は多数の硫化物が群落をなしているためき裂の 伝播が容䍙であり，加丁朴においても最も有害であると 言われている。このよらに鋯造材や加工材の機械的性質 が硫化物の形態や分们によつて大きな影響を受けること から，これらと鋼の組成別よび凝固条件などとの関係が 広範に研究されてきた5) 10). しかし，それらの多くは 光学顕微鏡的+イズの硫化物は凝固中に晶出したといら 前提に立つて行われているため，硫化物の挙動に与える 凝固後の冷却速度:の影響に対し，十分な配慮を払つてい るとは宁いがたい.

前々報11において，著者らは $\mathrm{Al}$ で強脱酸した若素鋼 における硫化物の形成機棈を検㣙し，西型に代表される
孤立分散型の硫化物は凝固後に固体鋼から析出すること を明らかにした．さらに前提 ${ }^{22}$ では，II型のように群落 をなして分布する硫化物の中にも固相内析出したものが あることを報告した。 そこで本報では凝固中のみなら ず，従来あまり考慮されることのなかつた凝固後の析出 過程にも注目し，低炭素キルド鋼中の硫化物の形成過程 を明らかにするとともに，その形態や分布を調査した結 果について報告する.

\section{2. 実 験 方 法}

\section{$\mathbf{2} \cdot \mathbf{1}$ 試 料}

試料の作製方法は前報 ${ }^{12)}$ と同様なので，ここでは概略 を述べるにとどめる． Fe-0.26\% Mn 合金を主材とし， これに成分調整用母合金および脱酸用 $\mathrm{Al}$ を加えて供試 材とした。こ机らを $1550^{\circ} \mathrm{C}$ に保持した $\mathrm{SiC}$ 炉に装入 し，脱酸生成物を浮上させるため，溶汀落ちてから約 2 $\mathrm{h}$ その温度に静置した後, 所定速度で泠却し, 目的の温 度から強攪汼水中に投入した。溶解および冷却中，炬内 は $\mathrm{Ar}$ 雾囲気に保たれ，また凝固中に対流が生じないよ らに試料に 3〜 5 ${ }^{\circ} \mathrm{C} / \mathrm{cm}$ の温度勾配を与元て, 下方から 一方向凝固させた.

得られたインゴットの大きさは直径約 $25 \mathrm{~mm}$, 高さ約 $40 \mathrm{~mm}$ であり，組成は Table 1 に示すとおりである.

将利 54 年: 11 月本会北海道支部講演会にて発表 炤和 56 年 8 月 25 日受付 (Received Aug. 25, 1981)

* 北海道大学:工学涓 (Faculty of Engineering, Hokkaido University, Nishi-8 Kita-13jo Kita-ku Sapporo 060)

*2 北海道大学工黄船工愽 (Faculty of Engineering, Hokkaido University) 


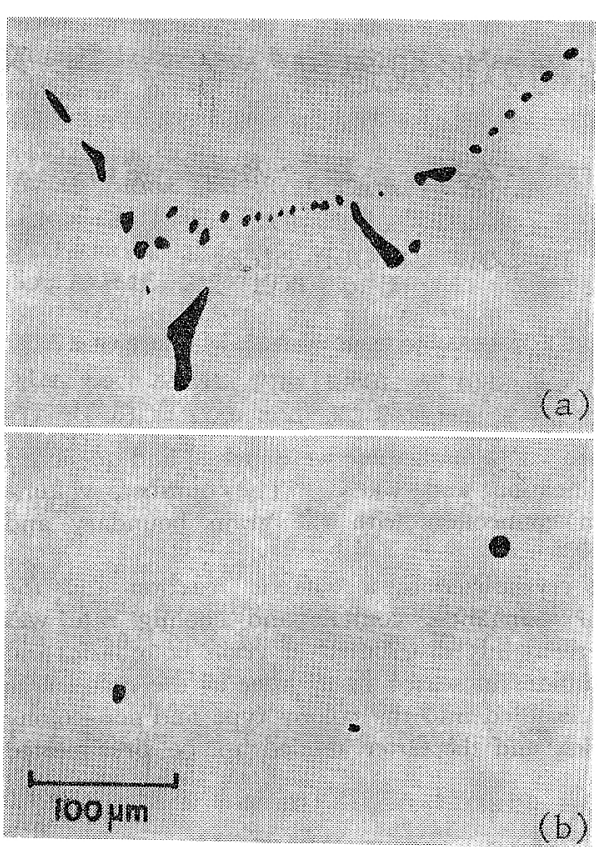

(a) Colony type sulflde (type $\mathrm{G}$ ).

(b) Non-colony type sulfide (type N).

Photo. 1. Glassification of sulfides.

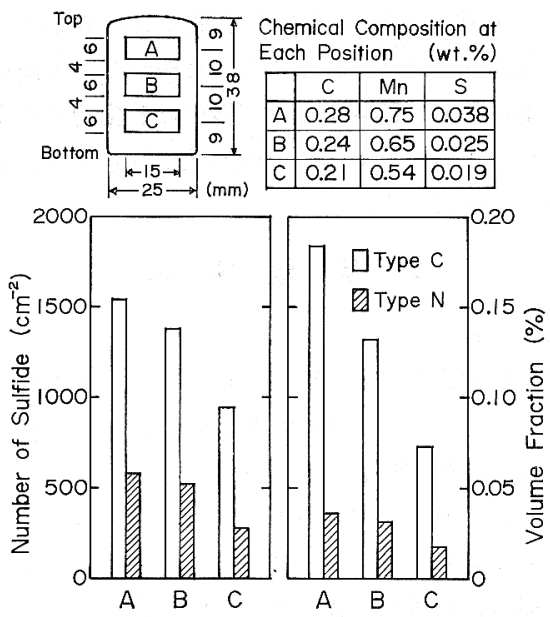

Fig. 1. The distribution of sulfides in series $6 \mathrm{M}$ ingot quenched at $700^{\circ} \mathrm{C}$. (Size of sulfides : > $1.5 \mu)$

な和，分析試料性インゴットの高さ方向中心から \pm 6

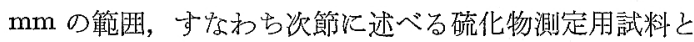
同じ位置から採取した.

\section{$2 \cdot 2$ 硫化物の測定}

前述したように，鋼中硫化物はその形態と分布からI 型，II型，III型に分類することが多い. しかし強脱酸鋼 で観察されるI型と亚型ね本質的に同じ形成機構（固相
内析出）を持つて特り ${ }^{11)}$ ，両者を区別する必然性は之し い. 先れゆ古本報では鋼の機械的性質に与光る影響の大 きさといら観点から，Photo.1（a）のように群落をな すもの（以後 C 型と呼ら゙） と, Photo. 1 (b) のように 孤立分散しているもの（以後N型と呼ら゙）の二つに分類 し，それぞれの数拐よび体積率を測定した。な特，G型 は従来の分類法では【型に，N型はI型㐨よび开型に相 当可る。

本実験試料はいずれも下から上に一方向凝固させてい るため，その方向に溶質元敃の濃度勾配が生じ，Fig. 1 に示すよらに硫化物の数や体積率も下から上へ之増加す る. そ孙党，分析試料の採取位置と検鏡試料のそれを 一致さ吨るとともに，各インゴット間で硫化物の測定位 置を統一する必要がある。本実験ではインゴット縊断面 の中心から高さ方向に $\pm 6 \mathrm{~mm}$, 值径方向に $\pm 10 \mathrm{~mm}$ の領域を設定し，そこに存在する直径約 $1.5 \mu$ 以上の 硫化物を対象に，光学顕微鏡倍率 400 倍，視野数約 2000 の条件で数括よび体樍率の測完を行つた。な和, 体積率測定には点算法（1 視野 400 格子点）を用いた。

\section{$2.3 \mathrm{Cr}$ 濃度分布図の作成}

硫化物がデンドライトのどのような位置に存在するか を明らかに一ることは，硫化物の成因，分布などを理解 する上で重要である。それ内光，前々報11ではPの，末 た前報12)ではMoの濃度分布がそれ先れデンドライト組 織と良く対応することを利用して，上記の関係を定量化 してきた，本報では，Pのように鋼の融点を大きく低下 させることがなく，また Mo を添加した場合よりも腐食 ハよるデンドライトの顕出が容易な Gr を灙度分布測定 用のトレーサー元素として用いた。

試料は $1000^{\circ} \mathrm{G}$ から急冷した 5\% Cr 鋼インゴット (Table 1 のシリーズ CR) の縦断面中央部から切り出 され， $4.5 \times 4.5 \mathrm{~mm}^{2}$ の領域を $50 \mu$ 間隔で XMA 分 析さ礼た。分析条件は加速電在 $25 \mathrm{kV}$ ，吸収雪流 0.04 $\mu \mathrm{A}$ ，単位測定時間 $10 \mathrm{~s}$ である. 得られた X 線強度は 検量線を用いて濃度（wt％）に変換され，それに基つい て $\mathrm{Gr}$ 等漫度線図を描いた。

Table 1. The compositions and cooling rates of samples.

\begin{tabular}{|c|c|c|c|c|c|c|c|c|}
\hline \multirow{2}{*}{ Series } & \multicolumn{7}{|c|}{ Composition (wt. \%) } & \multirow{2}{*}{$\begin{array}{l}\text { Cooling } \\
\text { rate } \\
\left({ }^{\circ} \mathrm{C} / \mathrm{min}\right)\end{array}$} \\
\hline & $\mathrm{G}$ & $\mathrm{Si}$ & $\mathrm{Mn}$ & $\mathrm{P}$ & S & Sol. Al & $\mathrm{Cr}$ & \\
\hline $3 \mathrm{M}$ & 0.24 & $<0.02$ & 0.29 & 0.014 & 0.026 & 0.07 & - & 0.5 \\
\hline $6 \mathrm{M}$ & 0.25 & $<0.02$ & 0.61 & 0.019 & 0.030 & 0.06 & - & 0.5 \\
\hline $12 \mathrm{M}$ & 0.23 & $<0.02$ & 1.15 & 0.018 & 0.028 & 0.06 & - & 0.5 \\
\hline $6 \mathrm{M}-\mathrm{GL}$ & 0.26 & 0.03 & 0.65 & 0.018 & 0.032 & 0.11 & - & $0.2 \sim 4.4$ \\
\hline $\mathrm{CR}$ & 0.26 & $<0.02$ & 0.32 & 0.019 & 0.025 & 0.11 & 5.31 & 1.0 \\
\hline
\end{tabular}




\section{3. 結果と考察}

\section{1 硫化物の形成過程におよぼす鋼中 $\mathrm{Mn}$ 濃度の影響}

凝固中拉上びそれ飞続く冷却中に和ける硫化物の晶出 ならびに 析出過程の 全容を明らかにするため，溶鋼を $0.5^{\circ} \mathrm{C} / \mathrm{min}$ で泠却し，凝固末期を含もさまざまな温度 から急冷した試料中の硫化物を観察した。 Fig. 2 と 3

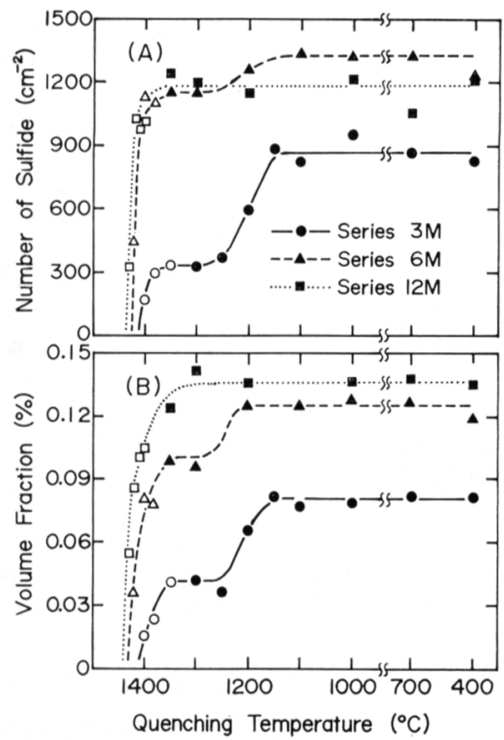

Fig. 2. The number and volume fraction of type $\mathrm{C}$ sulfides in ingots quenched at various temperatures. (Size of sulfides : $>1.5 \mu$ )

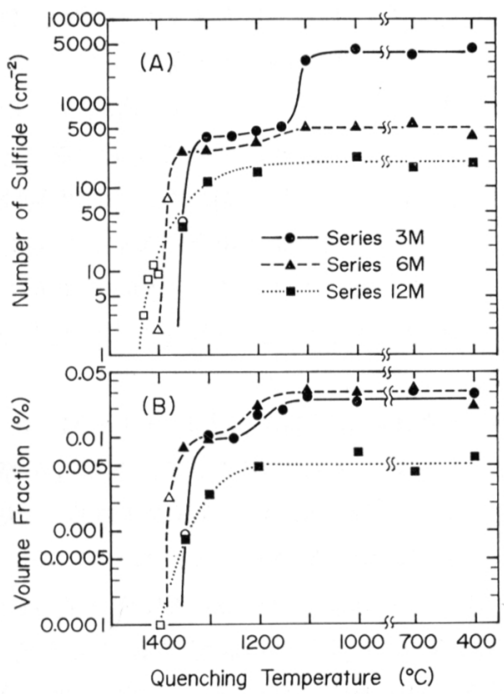

Fig. 3. The number and volume fraction of type $\mathrm{N}$ sulfides in ingots quenched at various temperatures. (Size of sulfides : $>1.5 \mu$ )
はシリーズ $3 \mathrm{M}, 6 \mathrm{M}$ および $12 \mathrm{M}$ 鋼について得られ た $\mathrm{C}$ 型ならびに $\mathrm{N}$ 型硫化物の数㐨よび体積率と急冷温度 の関係である. 図中の白抜き記号は Photo. 2 のように 融液が残存していた痕跡の認められた試料であり, 急冷 温度に执いて凝固が完了していなからたことを示してい る. Fig. 2 から明らかなように, C 型硫化物の形成過 程には二つの段階がある。最初の段階は凝固末期であ り, 硫化物は Photo. 2 の上うに融液と接して成長す る。前々報11でも述べたと拈り，鉄を初晶とする鋼にお

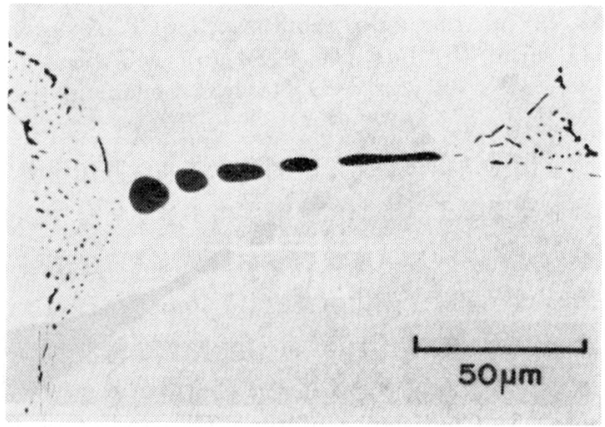

Photo. 2. Type $\mathrm{C}$ sulfides coexisting with melt in the series $6 \mathrm{M}$ ingot quenched at $1420^{\circ} \mathrm{C}$. The fine sulfide colony was crystallized during quenching.

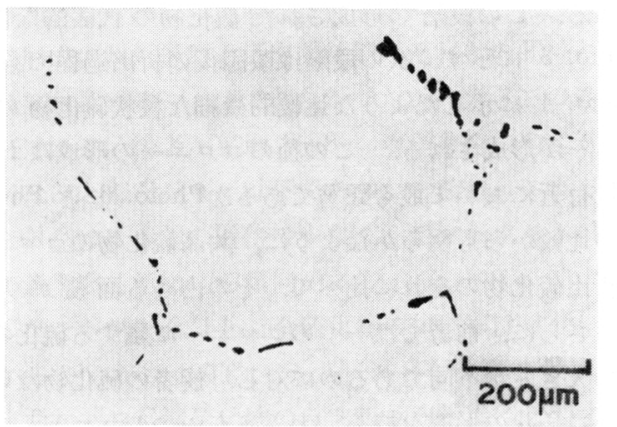

Photo. 3. Eutectic colony type sulfides (type $\mathrm{C}_{\mathrm{E}}$ ).

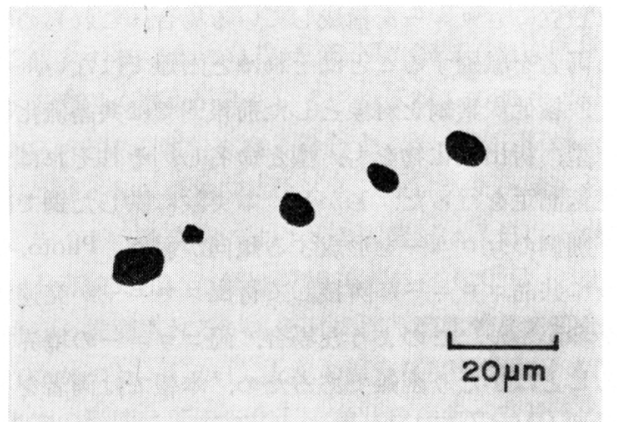

Photo. 4. Precipitated colony type sulfides (type $\mathrm{C}_{\mathrm{P}}$ ). 


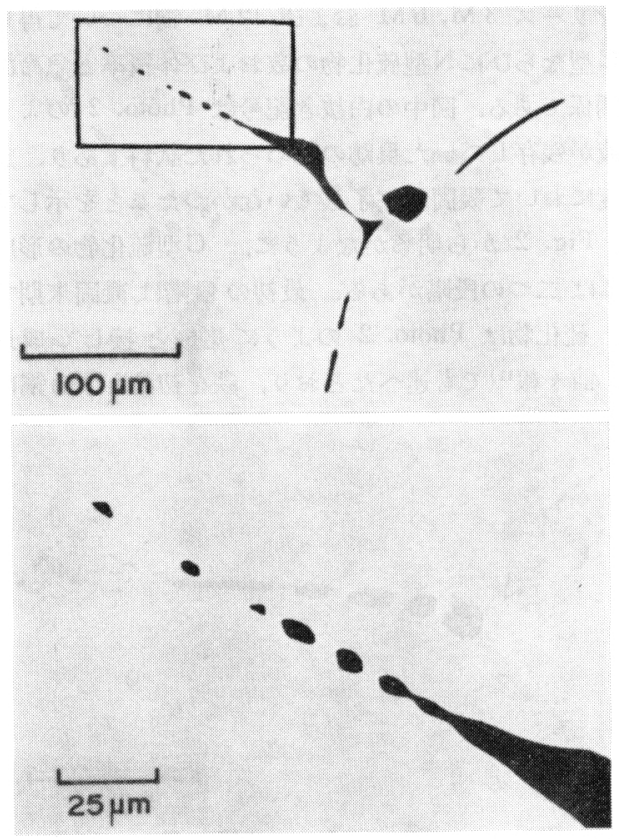

Photo. 5. Coexistence of type $\mathrm{C}_{\mathrm{E}}$ and type $\mathrm{C}_{\mathrm{P}}$ sulfides in the series $3 \mathrm{M}$ ingot quenched at 1150 ${ }^{\circ} \mathrm{C}$. A few type $\mathrm{C}_{\mathrm{P}}$ sulfides are observed at upper left part.

いて凝固末期に MnS を晶出する反応は共晶反応のみ である。この段階で形成された硫化物の代表的な例を Photo. 3 に示す. 次の段階は凝固後の析出過程であり, Photo. 4 に示したよらな比較的微細な粒状硫化物のコ ロニーが形成される。 この種のコロニーの形成は 1200 ${ }^{\circ} \mathrm{C}$ 付近に括いて最も顕著である. Photo. 3 と Photo. 4 の比較からも明らかなように, 共晶硫化物のコロニー は析出硫化物のそれに比べて，その占める面積が大き い.ささに, 前者では一つのコロニーに属する硫化物の 形や大きさが不同であるのに対し，後者の硫化物は球状 または角状の形態を持ち, 大きさも一つのコロニー内で は比較的そろつている. 共晶硫化物之析出硫化物がそれ ぞれ独立にコロニーを構成している場合, これらの特徵 から両者を識別することはそれほど困難ではない。年れ

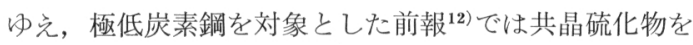
$\mathrm{C}_{\mathrm{E}}$ 型，析出硫化物を $\mathrm{C}_{\mathrm{P}}$ 型と命名し，それぞれについ て定量測定を行った。しかし，本実験に供した鋼では両 者が別個のコロニーを形成する傾向が弱く, Photo. 5 の ように共晶コロニーに隣接して析出コロニーが発達する 例が多かつた，このような場合，両コロニーの境界を決 めることはかなり困難であるため, 本報では両者をとも にC型として分類した.

Fig. 2 は鋼の Mn 濃度が増加するにつれて, G 型硫
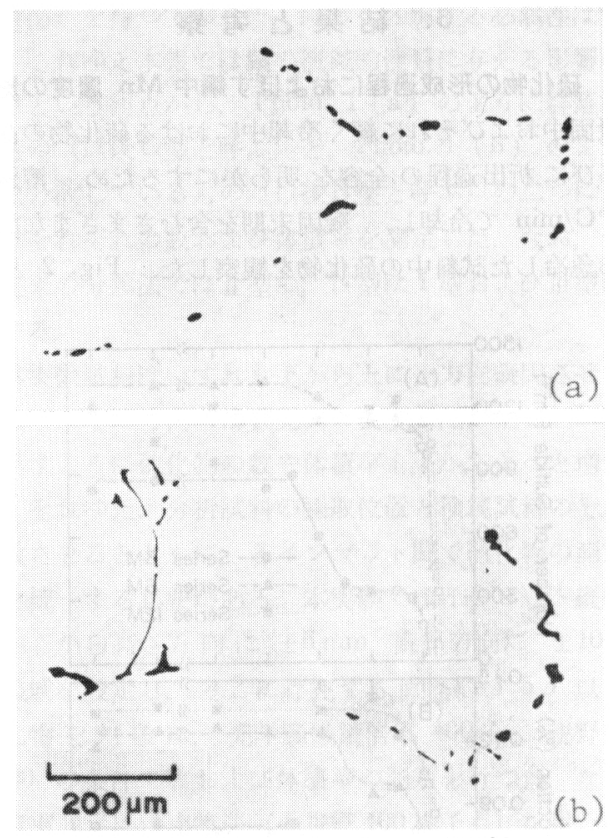

(a) Series $3 \mathrm{M}$ ingot quenched at $1000^{\circ} \mathrm{C}$.

(b) Series $12 \mathrm{M}$ ingot quenched at $1000^{\circ} \mathrm{C}$.

Photo. 6. The morphology change of type $\mathrm{C}_{\mathrm{E}}$ sulfides with increasing manganese content in steel.

化物の形成開始温度および融液の消失温度がともに高温 側に移行することを示している。融液の消失温度, すな わち凝固完了温度において，すでに $\mathrm{C}_{\mathrm{P}}$ 型之思われるコ ロニーが形成されている場合もあるが，午の数は非常に 少ない。したがつて, その付近の温度で観察される $\mathrm{C}$ 型 硫化物は大部分 $\mathrm{C}_{\mathrm{E}}$ 型であると考学られるが, 数, 体積 率ともにシリーズ $12 \mathrm{M}$ 鋼で最大となつている.さら に, Photo. 6 はコロニーの占める面積や個々の硫化物 の大きさも鋼の Mn 濃度によつて変化することを示し ている. すなわち, 低 $\mathrm{Mn}$ 鋼の $\mathrm{C}_{\mathrm{E}}$ 型硫化物は粒界を たどるかのよらに一列に並ぶ場合が多いのに対し， Mn 濃度が高くなると線状ではなく, 平面的な桩がりを持っ て分布する傾向が強くなり, それとともに長大な硫化物 が目立つよらになる。

Fig. 4 は著者らが以前に報告した Fe-Mn-S 系状態 図 ${ }^{13)}$ に基ついて描いた模式図である。 $\mathrm{S}$ 濃度が等しく, $\mathrm{Mn}$ 濃度の異なる鋼 $(\mathrm{X}, \mathrm{Y})$ が凝固する時, 未凝固残 液はそれぞれ $\mathrm{X}-\mathrm{X}^{\prime}, \mathrm{Y}-\mathrm{Y}^{\prime}$ の線に沿つて $\mathrm{Mn}$ と $\mathrm{S}$ 濃縮してゆき, 共晶線上の組成 $\left(\mathrm{X}^{\prime}, \mathrm{Y}^{\prime}\right)$ を持つに至 る. 点 $\mathrm{X}^{\prime}, \mathrm{Y}^{\prime}$ が共晶線の最高温点 $\mathrm{R}$ よりも低 $\mathrm{Mn}$ 側 にある場合, Mn 濃度の高い鋼ほど融液が共晶線に達す る温度, すなわち $\mathrm{C}_{\mathrm{E}}$ 型硫化物の晶出開始温度は高くな るはずであり，本実験はこの場合に相当する。ところ 


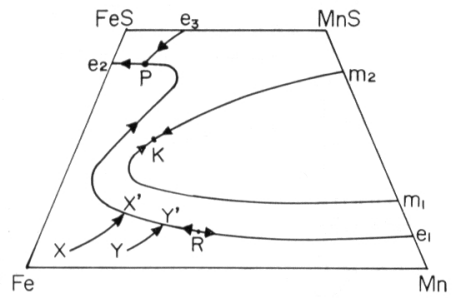

Fig. 4. Schematic diagram of the Fe-Mn-S system. Points $\mathrm{X}$ and $\mathrm{Y}$ represent initial compositions, respectively. Line $\mathrm{m}_{1}-\mathrm{k}-\mathrm{m}_{2}$ is a miscibility gap, and lines $e_{1}-p, e_{2}-p$ and $e_{3}-p$ are eutectic lines.

で，本実験で用いた鋼はいずれも初晶として $\delta$ 鉄を晶出 するが，凝固中に変態し， $\gamma$ 鉄として凝固を完了する。

鋼の Mn 濃度が増加するのに伴い， $\delta$ 鉄 ${ }^{12)}$ 抢よび $\gamma$ 鉄14)の $\mathrm{S}$ 固溶限は減少し，その結果融液中に排出される $\mathrm{S}$ 量が増加することを考劣るならば，高 $\mathrm{Mn}$ 鋼ほど $\mathrm{C}_{\mathrm{E}}$ 型硫化物の体積率が大きくなるという Fig. 2 の傾向 は当然期待されたところである. Fig. 4 で定性的に示 したように, Fe-Mn-S 系に扣ける共晶線の $\mathrm{S}$ 濃度は最 高温点 $\mathrm{R}$ から包共晶点 $\mathrm{P}$ に向かつて温度が下がるととも に増加与る ${ }^{13)}$ 。高 $\mathrm{Mn}$ 鋼では共晶線到達温度が高く，融 液中に排出される $\mathrm{S}$ 量が多いため, 硫化物晶出開始時の 融液量は低 Mn 鋼よりも多いにらがいない. 艺の結 果，Mn 濃度が高くなるにつれてデンドライト間隙など に孤立して捕捉される個々の共晶融液の体積も大さくな り，それから晶出する硫化物コロニーも良く発達するで あろう。この推測は Photo. 6 に示した高 Mn 鋼汪ど コロニーが発達するといら傾向を良く説明する。

凝固完了後に括汗る $\mathrm{C}$ 型硫化物数の増加は $\mathrm{C}_{\mathrm{P}}$ 型の析 出によるものであるが，これはFig. 2 からも明らかな よらに低 Mn 鋼渒ど顕著であり，特にシリーズ $3 \mathrm{M}$ 鋼 では数のみならず体積率に颃いても $\mathrm{C}_{\mathrm{E}}$ 型をしのぐに至 る. $\mathrm{C}_{\mathrm{P}}$ 型硫化物は Photo. 4 のような単独コロニーと して，あるいは Photo. 5 のような $\mathrm{C}_{\mathrm{E}}$ 型との複合コ口

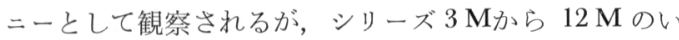
ずれの鋼においても前者は少数派であり, その傾向は高 $\mathrm{Mn}$ 鋼で特に著しい. $\mathrm{C}_{\mathrm{P}}$ 型硫化物の分布は単独コロニ 一と複合コロニーで異なり，後者が主にデンドライトの 樹間で観察されるのに対して, 前者はデンドライト組織 と無関係に分布していた.

N型硫化物が固相内析出物であることは前々報 ${ }^{11)} て ゙$ 述 べたと拈りであるが，Fig. 3 はこの析出過程に二つの 段階があることを示している，すなわら，最初の段階は 凝固完了直前から $1300^{\circ} \mathrm{C}$ にかけての析出開始期であ り, 次の段階は $1200^{\circ} \mathrm{G}$ から $1100^{\circ} \mathrm{C}$ にかけての微細



Photo. 7. Type $\mathrm{N}$ sulfides observed in (a) and (b) series $3 \mathrm{M}$, (c) series $6 \mathrm{M}$ and (d) series $12 \mathrm{M}$ steels quenched at $1000^{\circ} \mathrm{C}$.

硫化物析出期である。凝固完了温度付近で析出した $\mathrm{N}$ 型 は主にデンドライトの主軸または側枝上で観察され，樹 間に存在する $\mathrm{C}_{\mathrm{E}}$ 型とはその分布に括いて著しい対照を なしていた. Photo. 7 はこの段階で形成された代表的 な $\mathrm{N}$ 型硫化物の数例であり，いずれの鋼においても $(\mathrm{b})$ 〜 (d)のような角状硫化物が多数を占めるが，シリーズ $3 \mathrm{M}$ 鋼では（a）のような球状硫化物も少なからず観察 された。

$\mathrm{N}$ 型硫化物は $1200^{\circ} \mathrm{C}$ から $1100^{\circ} \mathrm{C}$ にかけて再び大 きく増加する．特にシリーズ $3 \mathrm{M}$ 鋼に特ける析出は劇的 であり，この間にN型の数は約 6 倍に増加した。 この段 階で形成された $\mathrm{N}$ 型と析出開始期のそれとの間に，形態 上の差を認めることはできなかつたが，大きさの違いは 顕著であり，後者が平均 $6 \sim 8 \mu$ の径を持つのに対し， 前者は汪とんどが $4 \mu$ 以下であつた。 な拉，これらの微 細な $\mathrm{N}$ 型は $\mathrm{C}_{\mathrm{E}}$ 型の近傍で少なく, デンドライトの周縁 部に最も多く析出する傾向がある.

C 型と N型を合計した全硫化物の体積率は Fig. 2 と 3 から明らかなよらに, シリーズ $12 \mathrm{M}$ 鋼で最大であ る. しかし， G 型硫化物のらち固相内析出に起因する凝 固完了後の増加分と $\mathrm{N}$ 型硫化物の体積率を合計した析出 硫化物の全量は $3 \mathrm{M}$ 鋼で最も多く, Mn 濃度の増加につ れて減少する。この結果は低 Mn 鋼汪ど温度降下に伴 う $\mathrm{S}$ 固溶限の減少が著しいことを示唆しており，TuRKDOGAN ら ${ }^{14)}$ の報告之良く符合する。一方，ROSENQVIST ら ${ }^{15)}$ の $\mathrm{Fe}-\mathrm{S}$ 系状態図によると, オーステナイトから $\alpha$ フェライトへの変態により $\mathrm{S}$ の固溶限は 2 倍以上増加す る. 本実験で用いた鋼は $750^{\circ} \mathrm{C}$ から $650^{\circ} \mathrm{C}$ の間で変 態すると推測されるが，それに伴う硫化物量の変化は見 られなかつた。しかし，上記の温度区間を冷却する間に， 硫化物の形態は若干変化し，角状硫化物が球状または角 状と球状の中間的形態へと移行する傾向を示した。 




Fig. 5. Relation between the cooling rate and number of sulfides in series $6 \mathrm{M}-\mathrm{CL}$ ingots quenched at (A) $1350^{\circ} \mathrm{C}$, (B) $1200^{\circ} \mathrm{C}$ and (C) $1000^{\circ} \mathrm{C}$. (Size of sulfides : >1.5 $\mu$ )

\section{$3 \cdot 2$ 硫化物の形成挙動に与える冷却速度の影響}

硫化物の量や形態に冷却速度が影響を与えるであるら ことは容易に予想されるところである. しかし，この点 に関する従来の研究はいずれも凝固過程を対象としてお

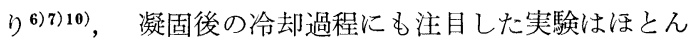
ど例を見ない，それゆ光，本節では Table 1 のシリー ズ $6 \mathrm{M}-\mathrm{CL}$ 鋼を溶融状態から $0.2 \sim 4.4^{\circ} \mathrm{C} / \mathrm{min}$ で冷却 し，所定温度から水冷したインゴットについて硫化物の 数と体積率を測定した. 結果を Fig. 5 および 6 に示 与.

Fig. 5 から明らかなように， C 型硫化物の数はいず れの温度においても冷却速度が大さくなるにつれて著し く増加する. 一方, 体積率の変化は Fig. 6 に見られる ように若干複雑であり， $1350^{\circ} \mathrm{C}$ と $1000^{\circ} \mathrm{C}$ では逆の 傾向を示した。前節で述べたように $1350^{\circ} \mathrm{C}$ で観察さ れる $\mathrm{C}$ 型硫化物はそのほとんどすべてが $\mathrm{C}_{\mathrm{E}}$ 型であり, 従つて Fig. 6(A) は冷却速度が大きくなると $\mathrm{G}_{\mathrm{E}}$ 型の 体積率も増加することを示している．この結果は冷却速 度が大さく, 拡散による固相内溶質濃度の均一化が困難 なほど，融液中に濃縮する溶質量が増すことを考えるな らば容易に理解される。急冷温度が低くなるにつれて， $\mathrm{S}$ 固溶限の減少に伴う $\mathrm{C}_{\mathrm{P}}$ 型の析出が起こり，その結果 $\mathrm{C}$ 型の体積率は増加する. この傾向は $\mathrm{Mn}$ や $\mathrm{S}$ の固相

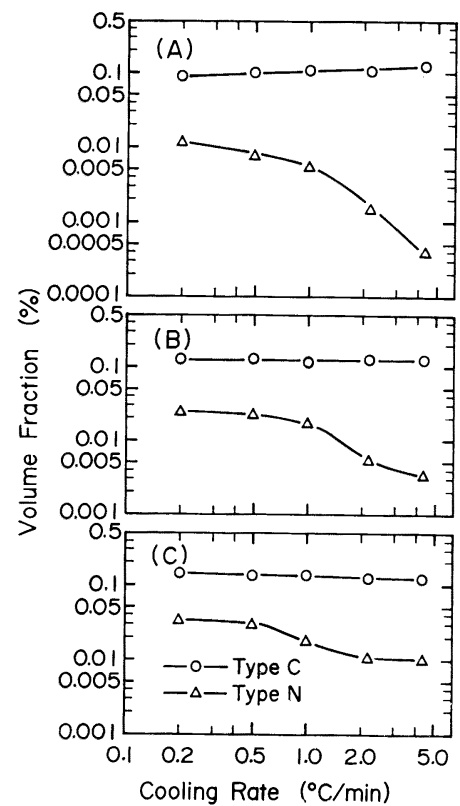

Fig. 6. Relation between the cooling rate and volume fraction of sulfides in series $6 \mathrm{M}-\mathrm{CL}$ ingots quenched at (A) $1350^{\circ} \mathrm{C}$, (B ) $1200^{\circ} \mathrm{C}$ and (C) $1000^{\circ} \mathrm{C}$. (Size of sulfides : $>1.5 \mu$ )

内拡散がより十分に起きる試料，すなわり冷却速度の小 さい試料泣ど顕著であり，1000 $\mathrm{C}$ から急冷した試料で は Fig. 6(C) のよらに冷却が遅いほどG 型硫化物の体 積率が大きいといら結果になつている.

$\mathrm{N}$ 型硫化物の体積率はいずれの急冷温度に招いても冷 却速度が小さくなるにつれて增加する．この傾向は， N 型硫化物が凝固後の析出物であり，したがつてその析出 量が固相内拡散に支配されることを考光れば当然の結果 である， $1000^{\circ} \mathrm{C}$ から急冷した試料に批ける $\mathrm{N}$ 型硫化物 の数は $\mathbf{G}$ 型の場合と同じく冷却速度とともに増加する.

しかし， $1350^{\circ} \mathrm{C}$ および $1200^{\circ} \mathrm{C}$ の試料では冷却速度 がそれぞれ $0.5^{\circ} \mathrm{C} / \mathrm{min}$ および $1.0^{\circ} \mathrm{C} / \mathrm{min}$ を超えると 逆に減少しており，これは多くの硫化物が测定対象とし た大きさ（約 $1.5 \mu$ ) まで成長できなかつたためであろ う. 以上の結果は $\mathrm{C}_{\mathrm{E}}$ 型が晶出硫化物であり， $\mathrm{C}_{\mathrm{P}}$ 型お よびN型が固相内析出物であるという前節で述べた形成 機構の妥当性を裏付けるとともに，硫化物量に与兄る凝 固後の冷却速度の影響が無視し得ないほどに大きいこと を示している.

Fig. 5 および 6 から明らかなよりに, 冷却速度は $\mathrm{C}$ 型と N型の形成比率にも影響を与をる。例えば $1000^{\circ} \mathrm{C}$ から急冷した試料について，全硫化物に占める C 型硫化 物の割合を求めると, 冷却速度が $0.2^{\circ} \mathrm{C} / \mathrm{min}$ では数に 
おいて 66\%，体積率に拈いて 80\% であるのに対し， $4.4^{\circ} \mathrm{C} / \mathrm{min}$ ではとれぞれ $90 \%$ および $92 \%$ にも達した。 このように冷却速度の増加は，鋼の機械的性質に多大の 害を与兄ると言われる $\mathrm{C}$ 型硫化物の形成を助長する.

\section{3 硫化物の分布之結晶粒界の関係}

Photo. 3 および 5 に見られたように, 多くの $\mathrm{C}_{\mathrm{E}}$ 型 および $\mathrm{C}_{\mathrm{P}}$ 型のコロニーは結晶粒界と密接な関係を持つ て分布しているよらに思われる。このよらな硫化物の増 加は粒界の脆化をもたらすため望ましくない。旮れゆ え, 本節では $\mathrm{C}$ 型および $\mathrm{N}$ 型硫化物が粒界上に形成され る頻度を定量的に調査した.

Fig. 7 はオーステナイトの粒界执よび粒内のそれぞ れに分布する直径約 $3 \mu$ 以上の硫化物数を，400 倍の光 学顕微鏡で 2000〜2 200 視野にわたつて 測定した 結果 である、本節で使用したシリーズ 3 M鋼は Fig. 2 から 明らかなよらに $1350^{\circ} \mathrm{C}$ から $1300^{\circ} \mathrm{C}$ の間で凝固を完 了する. 従つて, $1300^{\circ} \mathrm{C}$ で観察された C 型硫化物はほ とんどが $\mathrm{C}_{\mathrm{E}}$ 型であり，そのらち $32 \%$ が粒界上に存在 していた. 冷却が進むにつれて $\mathrm{C}_{\mathrm{P}}$ 型が析出するため, C 型硫化物の数は増加するが，それとともに粒界硫化物 の割合も増加し， $1200^{\circ} \mathrm{C}$ で $47 \% ， 1100^{\circ} \mathrm{C}$ では $55 \%$ に達した。冷却中に粒界が移動せず，一度形成された硫 化物が粒界から動かないと仮定すると， $1300^{\circ} \mathrm{C}$ から $1200^{\circ} \mathrm{C}$ 屯で泠却する間に形成される $\mathrm{C}_{\mathrm{P}}$ 型硫化物の $60 \%$ 以上が，また $1200^{\circ} \mathrm{C}$ から $1100^{\circ} \mathrm{C}$ の間ではそ のほとんどすべてが粒界に析出することになる。

一方， N型硫化物が粒界に析出する割合は $1300^{\circ} \mathrm{C}$ で はわずか $6 \%$ にすぎない。しかし，この割合は温度が 下がるにつれて増加し， $1200^{\circ} \mathrm{C}$ では $10 \%, 1100^{\circ} \mathrm{C}$ で は $22 \%$ が粒界で観察された。この結果を $\mathrm{C}$ 型の場合と

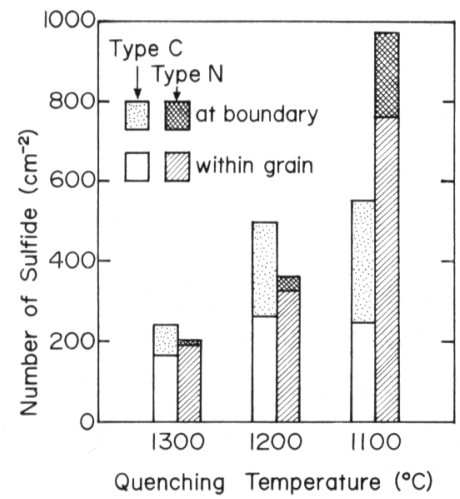

Fig. 7. Numbers of sulfides observed at austenite grain boundaries and within grains in series $3 \mathrm{M}$ ingot. (Size of sulfides : $>3 \mu$ )
同じ仮定のもとに計算すると， $1300^{\circ} \mathrm{C}$ から $1200^{\circ} \mathrm{C}$ の間で析出するN型の約 $20 \%$ が，また $1200^{\circ} \mathrm{C}$ から $1100^{\circ} \mathrm{C}$ の間で析出するものの約 $30 \%$ が粒界上に存在 寸ることになる。

以上のように， G 型も $\mathrm{N}$ 型も温度が下がるほど粒界に 存在する頻度が高く, $1300^{\circ} \mathrm{C}$ から $1100^{\circ} \mathrm{C}$ まで冷却す る間に粒界硫化物の数は $\mathrm{C}$ 型で 4 倍， $\mathrm{N}$ 型では実に 20 倍にも達し, 平均でも約 6 倍に増加する。な抏，この間 に扣将る粒内硫化物の増加は 3 倍に満たない。本節では 直径 $3 \mu$ 以上の比較的大きな硫化物の夕を測定している ため，1200 C 以下で析出する微細な硫化物の多くが対 象外になつている。それゆ充，上り微細な硫化物まで考 慮に大れるならば，降温に伴ら粒界硫化物の増加はさら に顕著になるであらう。

\section{4 硫化物の分布とデンドライト組織の関係}

著者らは前々報 ${ }^{11) て ゙ ~} \mathrm{P}$ を富化した $0.17 \% \mathrm{G}$ 鋼を用い て上記の関係を調査し，凝固中に生じる $\delta$ フライトか らオーステナイトへの変態が， N型硫化物の分布に影響 を与壳る可能性を示唆した. しかし，Pの富化は鋼の凝 固完了温度を大きく低下させ，これが硫化物の分布に影

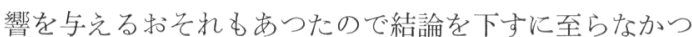
た，本報では上述の可能性を確認するために，凝固温度 に与える影響が小さく，またその濃度分布がデンドライ ト組織と良く対応寸る Cr を添加して同様の実験を行つ た.

Fig. 8 は Cr の 等濃度線図 であり, 平均濃度 (5.3 $\% \mathrm{Cr}$ )で描いた等濃度線が Photo. 8 のデンドライトの

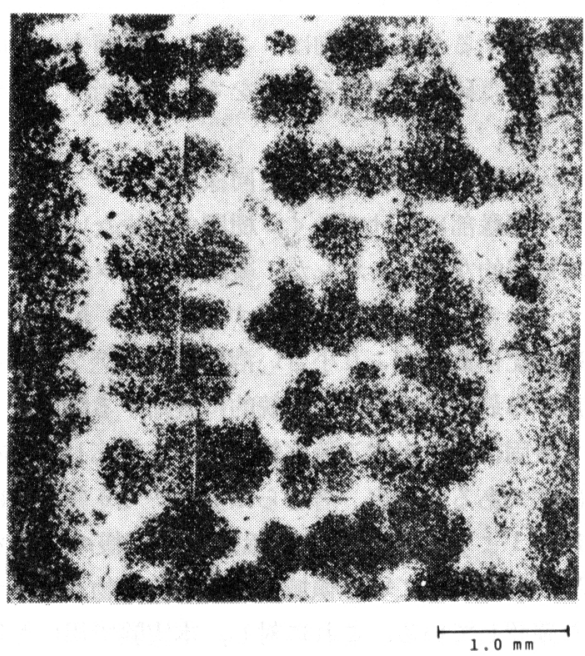

Photo. 8. Dendritic structure corresponding to Fig. 8. Light portions are interdendritic spaces. 


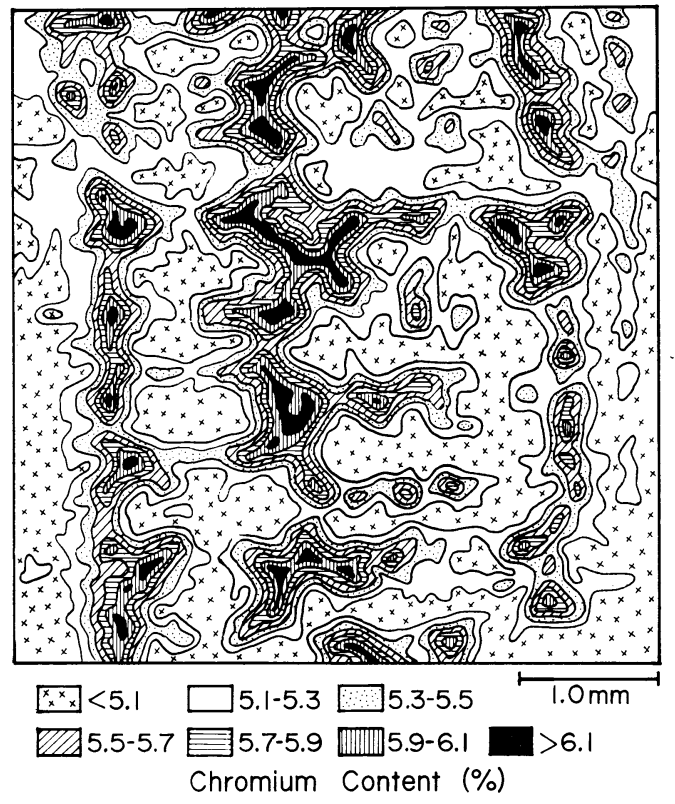

Fig. 8. Isoconcentration contour map of chromium in the longitudinal section of series $\mathrm{CR}$ ingot.

輸郭と良く一致している. Fig. 9 は Fig. 8 の各 Cr 濃 度範囲内に存在する約 $3 \mu$ 以上の硫化物数を測定した結 果であり， C 型硫化物がデンドライトの樹間に集中して いることを示している. Mn ほど顕著ではないが Cr に も硫化物の固相内析出を減少させる効果が認められるこ と，比較的大きな硫化物を測定対象としたことなどのた め, Fig. 9 に示した $\mathrm{G}$ 型硫化物は大部分が $\mathrm{C}_{\mathrm{E}}$ 型であ る. $\mathrm{C}_{\mathrm{E}}$ 型が最も $\mathrm{Cr}$ 濃度の高い領域, すなわち最終凝 固部に集中するといら傾向は，これらが凝固末期に融液 から晶出した硫化物であることを考劣れば当然の結果で ある。

一方， $\mathrm{N}$ 型硫化物は前々報と同様，デンドライトの中 心部から周縁部にかけて多く，樹間では少ないという $\mathrm{C}$ 型とは対照的な分布を示した. 凝固中に $\delta$ フェライトま たはオーステナイトのみを晶出する鋼では, Mn や $\mathrm{S} の$ ように分配係数が 1 より小さい溶質元素はデンドライト 中心部から最終凝固部へと連続的に濃縮するであろう. 従つて凝固後に析出する硫化物もそれと対応した分布を とるはずである，事実，著者らは前報12)で $\delta$ 凝固鋼に分 配係数が 1 より小さいMo を添加して同様の実験を行 い, Mo が濃縮している領域ほど $\mathrm{N}$ 型硫化物も増加する ことを確認している.これに対し，本実験で用いた鋼は 凝固初期に $\delta$ ェライトを，末期にオーステナイトを晶 出するが，両者は $\mathrm{S}$ 固溶限を異にし，前者では大きく，

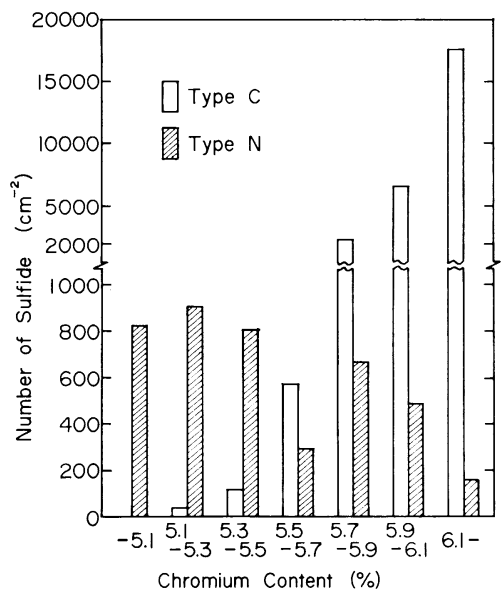

Fig. 9. The number of sulfides observed in each range of chromium content in series CR ingot.

(Size of sulfides : $>3 \mu$ )

後者では小さい，それゆ光，初期に凝固した领域は末期 に凝固した領域に比べて高い $\mathrm{S}$ 濃度を持つと考えられ， 冷却過程で析出する硫化物も前者の領域に多いである う、Pを富化した前々報の場合のみならず， Cr を加光 た本報においても $\mathrm{N}$ 型硫化物の分布が上の予測と一致し たこと，またこれらの鋼と前報の $\delta$ 凝国鋼ではN型の分 布が全く異なることなどから，凝固中に生じる。フェラ イトからオーステナイトへの変態が $\mathrm{N}$ 型硫化物の分布に 影響を与えることは明らかである.

以上述べてきたように，Fig. 9 に扔いて $\mathrm{N}$ 型硫化物 が樹間よりもデンドライト内に多い理由は凝固中に変態 が起きた結果として理解されるが， $\mathrm{C}_{\mathrm{E}}$ 型硫化物の分布 がN型のそれに与をる影響も無視することはできない。 すなわち, 冷却中に固溶限を超えた $\mathrm{S}$ の一部が夙辺の $\mathrm{C}_{\mathrm{E}}$ 型硫化物を肥大させるのに消費され，その結果 $\mathrm{C}_{\mathrm{E}}$ 型の 密集している領域では $\mathrm{N}$ 型が減少する可能性がある. Fig. 9 の $\mathrm{Gr}$ 濃度 $6.1 \%$ 以上の領域でN型が大きく減 少しているのはこのような理由によるものであるう。

\section{4. 結訔}

低炭素鋼に打壮る $\mathrm{MnS}$ 系介在物の形成過程を明らか にするため，0.25\% C, 0.3 1.2\% Mn および $0.03 \% \mathrm{~S}$ を含む溶鋼を所定速度で冷却し，凝国末期を含を種々の 温度から急冷した．これらの鋼について，硫化物の数お よび体積率を測定するとともに，硫化物の分布とオース テナイト結晶粒界およびデンドライト組織との関係を調 査し, 以下の結果を得た。

（1）硫化物はその形成過程から，凝固末期に共晶反 
応によつて形成されるものと，凝固後に固体鉄から析出 するものに大別することができる.

（2）其晶反応によつて晶出した硫化物は不規則な形 態を持つ比輘的粗大な粒子の集団として観察され， $\mathrm{C}_{\mathrm{E}}$ 型 と名付けられた。 $\mathrm{C}_{\mathrm{E}}$ 型硫化物は $\mathrm{Mn}$ 濃度の高い鋼や 冷却速度の大きい鋼に多く，また結晶粒界およびデンド ライトの樹閒に分布する傾向が強かつた。

（3）凝固後に析出する硫化物はその分布から集団を なすもの之，㧓立分散しているものに分類され，それぞ れ $\mathrm{C}_{\mathrm{P}}$ 型およびN型と名付けられた。いずれも角状また は球状形態を持つ比較的微細な硫化物であり, $\mathrm{Mn}$ 濃度 の低い鋼や冷却の遅い鋼で多数钼察される， $\mathrm{C}_{\mathrm{P}}$ 型は $\mathrm{C}_{\mathrm{E}}$ 型と共存する場合が多く, 従つて分布も $\mathrm{C}_{\mathrm{E}}$ 型と類似し ているが，結晶粒界に存在する傾向は $\mathrm{C}_{\mathrm{E}}$ 型よりもさら に顕著である。一方，N型は結唱粒内に多く，またデ ンドライトの主軸および側枝上に分布する傾问が強い。

終わりに，素材の提供ならびに試料の分析をしていた だいた(株)日本製鋼所，空蘭製作所に愿く感謝 致しま †.

\section{文献}

1) C. E. Sims : Trans. AIME, 215 (1959), p. 367

2) $T . J$. Baker and $J . A$. Charles: JiSi, 211
(1973), p. 187

3 ) $W$. Dahl, $H$. Hengstenberg, and $C$. Düren: Stahl u. Eisen, 86 (1966), p. 796

4) $T . J$. Baker and $J . A$. Charles: Effect of Second Phase Particles on the Mechanical Properties of Steel (1971), p. 79 [ISI]

5 ) $W$. Dahl, $H$. Hengstenberg, and $C$. Düren: Stahl u. Eisen, 86 (1966), p. 782

6 ) P. P. Mohla and J. Beech: JISI, 207 (1969), p. 177

7 ) K. Schwerdtreger: Arch Eisenhüttenw., 41 (1970), p. 923

8 ) $H$. Fredriksson and M. Hillert: Scand. J. Met., 2 (1973), p. 125

$9)$ L. K. Bigelow and M. C. Flemings: Met. Trans., 6B (1975), p. 275

10) 商田 为，别所 勇，伊藤孝道：鉄と鋼，62 (1976), p. 1319

11）做藤洋一，升光法行，松原嘉市：鉄と鋼，66 (1980), p. 647

12）伊藤洋一，成田信弘，松原嘉市：鉄と鋼，67 (1981), p. 755

13）伊藤洋一，米澤 襄，松原嘉市：鉄と鋼，65 (1979), p. 391

14) E. T. Turkdogan, $S$. Ignatowicz, and $J$. Pearson: Jisi, 180 (1955), p. 349

15) T. Rosenovist and B. L. Dunicz: Trans. AIME, 194 (1952), p. 604 